\title{
Solutions and strategies of Nezahualcoyotl's business before the pandemic
}

\author{
Soluciones y estrategias de los negocios de Nezahualcóyotl ante la pandemia
}

\author{
GUTIÉRREZ-ZEPEDA, Martha del Pilar*†
}

Universidad Tecnológica de Nezahualcóyotl

ID $1^{\text {st }}$ Author: Martha del Pilar, Gutiérrez-Zepeda / ORC ID: 0000-0003-0256-8874

DOI: $10.35429 / J M M E .2020 .7 .4 .16 .27$

Received July 20, 2020; Accepted December 10, 2020

\begin{abstract}
This work helped us to understand the problems faced by businesses in the Nezahualcóyotl city and the metropolitan area in order to generate the appropriate strategies to help them to increase sales without large investments,for this purpose a non-experimental research was carried out with a quantitative approach and a descriptive design taking into account a probabilistic sample of 370 surveys randomly with a confidence interval of $95 \%$ and a single error of 5\%, the data collection instrument is a structured questionnaire with closed questions for a greater objectivity and to ensure that the collection instrument was appropriate it was carried out a pilot test of $10 \%$ of the sample, it was in order to consider that the interpretation of the questions were appropriate, when the final questionnaire was applied the result was that the $41 \%$ of respondents were from Neza, besides it telling us that only $8 \%$ of traders received help according to financial support programs for companies and in relation to strategies that most generated a sales increase, $45 \%$ of businesses use home deliveries and 53\% tell us that they advertise through social media. On the other hand, it is proposed that Facebook will be the social network that help them to spread their products in addition to sending stories related to them so that they had a better use and to create loyalty of the product in addition to home delivery with sanitary and safe conditions established by the Health sector to provide confidence to the customer. Thanks to this project, traders who can read thisproject will have a better view of the solutions they may have to move forward and not to be part of that $35 \%$ of bisinesses to close because of the pandemic.
\end{abstract}

Business, Pandemic, Solutions

\begin{abstract}
Resumen
Este trabajo nos ayudó a conocer los problemas a los que se enfrentan los negocios en el municipio de Ciudad Nezahualcóyotl y el área metropolitana con el propósito de generar estrategias apropiadas para ayudarles a aumentar las ventas sin inversiones grandes, para ello se llevó a cabo una investigación no experimental con un enfoque cuantitativo y un diseño descriptivo teniendo en cuenta una muestra probabilística de 370 encuestas de forma aleatoria con un intervalo de confianza del $95 \%$ y un error solo del 5\%, el instrumento de recolección de datos es un cuestionario estructurado con preguntas cerradas para una mayor objetividad y para asegurarse de que el instrumento de recolección era apropiado se realizó una prueba piloto del $10 \%$ de la muestra, se llevó a cabo con el fin de considerar que la interpretación de las preguntas eran adecuadas, al aplicar el cuestionario definitivo nos dio como resultado que el $41 \%$ de los encuestados provenían del área de Neza, también nos dice que sólo el $8 \%$ de los comerciantes recibieron ayuda de acuerdo a los programas de apoyo financiero para empresas y en relación a las estrategias que más a generado un incremento de ventas, el $45 \%$ de los negocios utilizan las entregas a domicilio y el 53\% nos dice que realizan su publicidad a través de las redes sociales. Por otro lado, se propone que Facebook sea la red social que les ayude a difundir sus productos además de enviar historias relacionadas con ellos para un mejor uso de estos para crear fidelidad del producto además de la entrega a domicilio con condiciones sanitarias establecidas por el sector Salud para que brinde seguridad y confianza al cliente. Gracias a este proyecto, los comerciantes que tienen el alcance de esta lectura tendrán una mejor imagen de las soluciones que pueden tener para avanzar y no ser parte de ese $35 \%$ del cierre de su negocio.
\end{abstract}

Negocios, Pandemia, Soluciones

Citation: GUTIÉRREZ-ZEPEDA, Martha del Pilar. Solutions and strategies of Nezahualcoyotl's business before the pandemic. RINOE Journal- Macroeconomics and monetary economy. 2020. 4-7: 16-27

\footnotetext{
* Correspondence to Author (e-mail: martha.gutiérrezze@utn.edu.mx)

$\dagger$ Researcher contributing first author.
} 


\section{Introduction}

At the end of 2019 the world detected a new virus that is passed from person to person, affecting mainly those who have low defenses, the virus became known as SARs-Cov2 (known worldwide as COVID-19), it began in China, it spread towards Europe and finally arrived in Mexico and the first case was made known in February of this year. As of April, the CDMX was put on a red alert and businesses were closed, then in March schools were closed throughout the country, also on those dates sanitary measures began such as the use of face masks, use of gel, constant hand washing with soap and water for 20 seconds and avoid all kinds of public and / or private meetings with a maximum capacity of 30 people and not leave the house only for what is necessary and take care of the elderly, for all these measures the businesses from this date on, most did not have complete knowledge of what was really happening, some commented that it was a smoke screen by the Federal Government, others that it was part of a plan for a businessman to sell more products and there was no certainty of finding out about COVID-19.

The vast majority of people did not continue with their normal lives, affecting the demand for their businesses every day more, after one of the measures that affected a lot and $\mathrm{n}$ the economic activity was the official provision for the closure of businesses and companies according to the red traffic light as a measure of physical distancing as indicated by the guidelines for estimating traffic light risks by COVID-19 regions (Ministry of Health, August2020)

The COVID-19 pandemic has affected many businesses from all over the world, but in this research we will only focus on small businesses in Nezahualcóyotl and the Metropolitan Area in order to know which business line is the most affected and thus with the data that will be obtained, carry out strategies that help businesses in need.
A non-experimental research was carried out taking into account a quantitative approach and a descriptive design with a random probabilistic sample and the collection instrument is a questionnaire with closed questions to take care of the objectivity of the investigation and according to the Universe of 9973 businesses that are found registered in MyPES in Nezahualcóyotl, Chalco, Chimalhuacán, Texcoco, Ixtapaluca and Los Reyes la Paz, with a confidence interval of $95 \%$ and an error of $5 \%$, therefore the survey was applied to 370 businesses online and in person.

To take care of the structure of the questionnaire, a pilot test of $10 \%$ of the sample was applied to ensure that the questions were the ideal ones to solve this investigation, after obtaining results the graphs and the interpretation of each question are made, which are essential to conclude with appropriate strategies such as promoting your business through Facebook, in addition to adding stories of content related to the business that is offered as suggested by Merca2.0 magazine where it indicates that there are three keys to success, taking into account that today millennials are the generational segment that most demands from online portals to place a photograph, an emotional description and an appropriate price (Letayf J, 2020) to make them known to businesses and thus they can increase their sales. In addition to home delivery with the sanitary measures recommended by the Health Sector so that customers are not fearful. That is why this research is of great importance due to the implementation of appropriate strategies without the need to invest more than budgeted since you can earn more, while offering security and your client their loyalty.

\section{Chapter I Method}

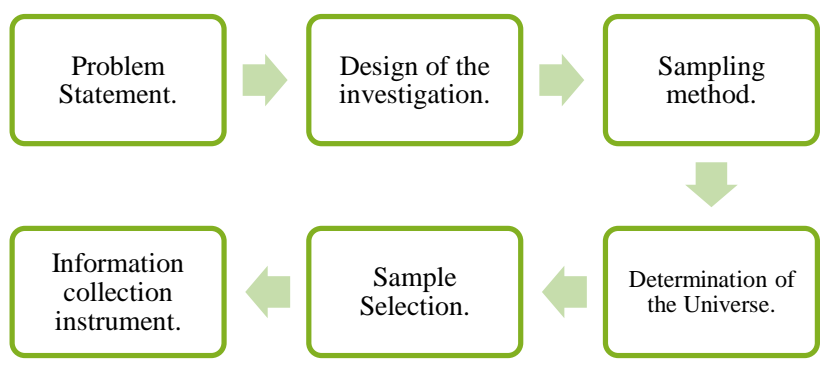

Figure 1.1 Research method

Source of consultation: Own Authorship 


\section{Problem Statement}

According to the Survey on the Economic Impact Generated by COVID-19 (ECOVID-IE), prepared by the National Institute of Statistics and Geography (INEGI), (INEGI, 2020) communicates the following results in relation to the consequences of the Sanitary measures especially in the one of "Stay at home" due to the ignorance on the part of the Population of this Virus considered in only buying basic basket and another type of product stopped buying it for that reason there is a low demand of $72.6 \%$.

Little by little, unfortunately, the most affected businesses were small with $92 \%$, later companies and small and medium-sized companies in $87.8 \%$ and it fell a little for large companies compared to the previous ones only $35.9 \%$ and as a consequence the reductions arise of salaries and / or benefits to their workers up to $41.8 \%$, followed by medium and small companies in $20.6 \%$ and by micro companies only $18.8 \%$, while other entrepreneurs took more resounding strategies such as the dismissal of staff.

Large companies cut their staff by $22.3 \%$, followed by medium and small companies by $18.6 \%$ and by micro companies only by $15.1 \%$. Subsequently, support arises for entrepreneurs in order to reactivate the Mexican economy, but only $7.8 \%$ enjoyed this help.

On the other hand, in a Nezahualcóyotl bulletin where he talks about the participation of merchants where there are more than 1,800 applications for the economic credit program in addition to the temporary employment program to benefit more than 900 inhabitants who have stayed. without work due to the pandemic in order to support the Municipal Economic Reactivation program (Press Release 2020)

With all this, if it is important to investigate promptly if the support that has been generated by the government has helped the vast majority or if the businesses have learned of the support that has arisen as a consequence of this new normal, therefore it is necessary know the opinion of the same merchants who have suffered these consequences derived from the pandemic and know how they have resolved it

How have businesses solved the problems caused by this pandemic?

\section{General purpose}

Know the solutions that businesses that have suffered during this pandemic have taken through non-experimental research taking into account a quantitative approach and a descriptive design to propose adequate strategies to merchants in Nezahualcóyotl and the Metropolitan Area.

\section{Specific objectives}

- Know how businesses have suffered
from the pandemic.
Obtain statistical data on business
impacts
Guide business based on research results

\section{Hypothesis}

As of the date that the pandemic was in Mexico, businesses were closed as of April. Being the date in which many businesses without having the knowledge of such magnitude some were informed, but the great majority of the population and especially those who do not work in places that closed continued with normal life. The solutions that are considered to be carried out by companies, especially businesses, were the support of the municipal government such as: support with cash transfers to businesses that need to invest to avoid total closure; loans with subsidized interest rates; tax support for payroll; deferral of credit payments for businesses that do not have cash to pay at the moment, giving them more time to pay off loans. On the other hand, another of the strategies considered could be the dissemination of their products through social networks, especially on Facebook, the number one advertising network used in businesses and in the majority of the population in Nezahualcóyotl and the metropolitan area. In addition to strategies more directed to the type of sector that our company is in. as home delivery.

\section{Justification}

This research focuses on the businesses in Nezahualcóyotl and the Metropolitan Area that were affected by the pandemic in order to help increase their sales by generating appropriate strategies in business through orientation according to the results of the investigation in order to to contribute with new sales ideas for businesses to support an economic reactivation of the place. 


\section{SWOT}

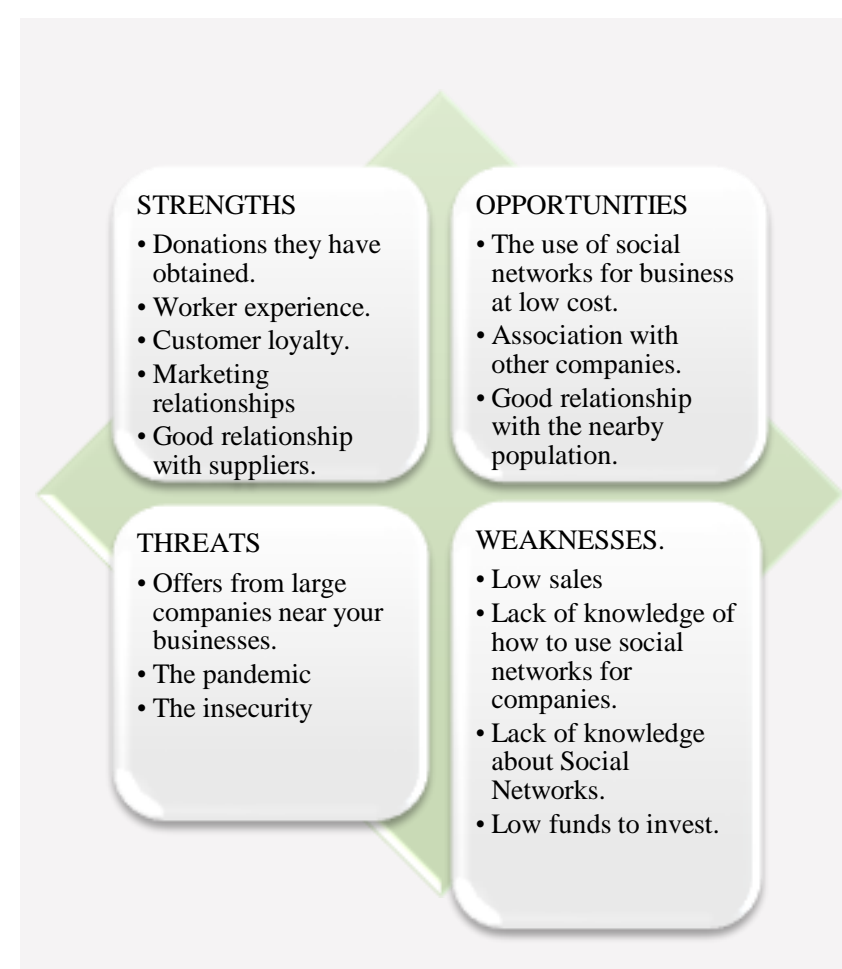

Figure 1.2 SWOT of local companies

Source of consultation: According to the theoretical framework investigated

\section{Design of the investigation}

This research is with a Quantitative Approach because it wants to know with the necessary and concise information to be able to have an answer to the question of the problem statement. Our design is developed through non-experimental Transectional, descriptive research in order to obtain recent information from statistical data on the impact that businesses have had in the face of the pandemic in addition to knowing which business line is the most affected, taking into account account of the knowledge of the people who are having the experience of what has caused this confinement.

\section{Sampling method}

\section{Random Probabilistic Sampling}

Develop a probability sampling because not all businesses will be selected for the investigation since businesses registered in MyPes are being taken into account, in order to obtain information that helps us to know which business is the most affected to later make proposals or strategies that help increase sales.

\section{Determination of the universe}

To determine the universe, it was necessary to carry out a documentary investigation where the total number of businesses that are registered in MyPES in the municipality of Ciudad Nezahualcóyotl and the metropolitan area is known, to calculate the ideal sample for this investigation, as shown in the following tables:

\begin{tabular}{|l|r|}
\hline Business in the Metropolitan Area & Neza \\
\hline Food & 216 \\
\hline Pharmacy & 108 \\
\hline Grocery stores & 133 \\
\hline Miscellany & 241 \\
\hline Naturist & 45 \\
\hline Internet And Gift Shop & 1 \\
\hline Cremeria & 34 \\
\hline Rigging & 100 \\
\hline Raw Materials & 45 \\
\hline Juices & 287 \\
\hline Pizza shop & 34 \\
\hline Laundry & 88 \\
\hline Dry cleaner & 59 \\
\hline Cake shop & 216 \\
\hline Bakery & 50 \\
\hline Tortilleria & 38 \\
\hline Stationery & 41 \\
\hline Poultry & 214 \\
\hline Butcher shop & 99 \\
\hline Purifying & 33 \\
\hline Stockpile & 34 \\
\hline Tlapalería & 60 \\
\hline Cell Phone Accessories & 14 \\
\hline Washer Repairman & 1 \\
\hline Bonnet store & 266 \\
\hline Internet & 15 \\
\hline Furniture & 1 \\
\hline Tatto & 20 \\
\hline Aesthetics And Hairdressing & 12 \\
\hline Veterinary & 258 \\
\hline Billiards & 87 \\
\hline Carpentry & 93 \\
\hline Plumbing & 210 \\
\hline Mechanics & 1 \\
\hline Shoe shop & 28 \\
\hline Smithy & 46 \\
\hline
\end{tabular}

Table 1.1 Nezahualcóyotl Business Number Source: Pymes.org.mx 


\begin{tabular}{|l|r|}
\hline Business in the Metropolitan Area La Paz \\
\hline Food & 46 \\
\hline Pharmacy & 410 \\
\hline Grocery stores & 262 \\
\hline Hardware & 115 \\
\hline Raw Materials & 201 \\
\hline Juices & 128 \\
\hline Pizza shop & 12 \\
\hline Laundry & 95 \\
\hline Dry cleaner & 57 \\
\hline Cake shop & 81 \\
\hline Bakery & 159 \\
\hline Tortilleria & 353 \\
\hline Stationery & 22 \\
\hline Poultry & 425 \\
\hline Butcher shop & 245 \\
\hline Purifying & 229 \\
\hline Clothing store & 88 \\
\hline Stockpile & 199 \\
\hline Tlapalería & 234 \\
\hline Cell Phone Accessories & 27 \\
\hline Internet & 256 \\
\hline Miscellany & 267 \\
\hline Naturist & 37 \\
\hline Cremeria & 223 \\
\hline Bonnet store & 67 \\
\hline Carpentry & 134 \\
\hline Plumbing & 22 \\
\hline Mechanical & 4 \\
\hline Shoe shop & 3 \\
\hline Smithy & 191 \\
\hline Tatto & 5 \\
\hline Vet & 3 \\
\hline Esthetic & 2 \\
\hline Furniture & 41 \\
\hline Billiards & 11 \\
\hline
\end{tabular}

Table 1.2 Number of Businesses in Los Reyes La Paz Source: Pymes.org.mx

\begin{tabular}{|l|r|}
\hline Business in the Metropolitan Area Ixtapaluca \\
\hline Food & 34 \\
\hline Pharmacy & 260 \\
\hline Grocery stores & 64 \\
\hline Hardware & 50 \\
\hline Raw Materials & 119 \\
\hline Juices & 52 \\
\hline Pizza shop & 6 \\
\hline Laundry & 75 \\
\hline Dry cleaner & 32 \\
\hline Cake shop & 31 \\
\hline Bakery & 67 \\
\hline Tortilleria & 196 \\
\hline Stationery & 476 \\
\hline Poultry & 244 \\
\hline Butcher shop & 151 \\
\hline Purifying & 73 \\
\hline Clothing store & 47 \\
\hline Stockpile & 140 \\
\hline Tlapalería & 135 \\
\hline Cell Phone Accessories & 4 \\
\hline Internet & 145 \\
\hline Miscellany & 471 \\
\hline Naturist & 17 \\
\hline
\end{tabular}

ISSN-On line: $2524-2040$

RINOE $^{\circledR}$ All rights reserved.

\begin{tabular}{|l|r|}
\hline Cremeria & 111 \\
\hline Bonnet store & 13 \\
\hline Carpentry & 63 \\
\hline Plumbing & 10 \\
\hline Mechanical & 105 \\
\hline Shoe shop & 25 \\
\hline Smithy & 94 \\
\hline Tatto & 8 \\
\hline Vet & 33 \\
\hline Esthetic & 0 \\
\hline Furniture & 19 \\
\hline Billiards & 8 \\
\hline
\end{tabular}

Table 1.3 Number of Businesses in Ixtapaluca Source: Pymes.org.mx

\begin{tabular}{|l|r|}
\hline Business in the Metropolitan Area Texcoco \\
\hline Food & 67 \\
\hline Pharmacy & 288 \\
\hline Grocery stores & 160 \\
\hline Hardware & 28 \\
\hline Raw Materials & 75 \\
\hline Juices & 90 \\
\hline Pizza shop & 11 \\
\hline Laundry & 224 \\
\hline Dry cleaner & 69 \\
\hline Cake shop & 82 \\
\hline Bakery & 115 \\
\hline Tortilleria & 242 \\
\hline Stationery & 651 \\
\hline Poultry & 246 \\
\hline Butcher shop & 258 \\
\hline Purifying & 65 \\
\hline Clothing store & 95 \\
\hline Stockpile & 173 \\
\hline Tlapalería & 136 \\
\hline Cell Phone Accessories & 6 \\
\hline Internet & 289 \\
\hline Miscellany & 363 \\
\hline Naturist & 33 \\
\hline Cremeria & 96 \\
\hline Bonnet store & 42 \\
\hline Carpentry & 90 \\
\hline Plumbing & 12 \\
\hline Mechanical & 162 \\
\hline Shoe shop & 145 \\
\hline Smithy & 127 \\
\hline Tatto & 11 \\
\hline Vet & 11 \\
\hline Esthetic & 3 \\
\hline Furniture & 30 \\
\hline Billiards & 6 \\
\hline
\end{tabular}

Table 1.4 Number of Businesses in Texcoco Source: Pymes.org.mx

According to the total number of businesses in Nezahualcóyotl and the Metropolitan Area, there are 9,973 businesses affected by the covid-1 pandemic equivalent to the Universe that will be taken as the basis for our investigation. 
December, 2020 Vol.4 No.7 16-27

\begin{tabular}{|l|r|}
\hline Business in the Metropolitan Area & Chimahualcan \\
\hline Food & 85 \\
\hline Pharmacy & 775 \\
\hline Grocery stores & 420 \\
\hline Hardware & 385 \\
\hline Raw Materials & 376 \\
\hline Juices & 234 \\
\hline Pizza shop & 22 \\
\hline Laundry & 179 \\
\hline Dry cleaner & 99 \\
\hline Cake shop & 151 \\
\hline Bakery & 354 \\
\hline Tortilleria & 131 \\
\hline Stationery & 445 \\
\hline Poultry & 138 \\
\hline Butcher shop & 235 \\
\hline Purifying & 497 \\
\hline Clothing store & 246 \\
\hline Stockpile & 219 \\
\hline Tlapalería & 598 \\
\hline Cell Phone Accessories & 27 \\
\hline Internet & 452 \\
\hline Miscellany & 387 \\
\hline Naturist & 81 \\
\hline Cremeria & 549 \\
\hline Bonnet store & 133 \\
\hline Carpentry & 224 \\
\hline Plumbing & 73 \\
\hline Mechanical & 3 \\
\hline Shoe shop & 241 \\
\hline Smithy & 475 \\
\hline Tatto & 11 \\
\hline Vet & 7 \\
\hline Esthetic & 31 \\
\hline Furniture & \\
\hline Billiards & 27 \\
\hline & 2 \\
\hline
\end{tabular}

Table 1.5 Number of Businesses in Chimalhuacán

\begin{tabular}{|l|r|}
\hline Business in the Metropolitan Area & Chalco \\
\hline Food & 63 \\
\hline Pharmacy & 412 \\
\hline Grocery stores & 572 \\
\hline Hardware & 156 \\
\hline Raw Materials & 213 \\
\hline Juices & 105 \\
\hline Pizza shop & 20 \\
\hline Laundry & 125 \\
\hline Dry cleaner & 41 \\
\hline Cake shop & 89 \\
\hline Bakery & 177 \\
\hline Tortilleria & 477 \\
\hline Stationery & 248 \\
\hline Poultry & 460 \\
\hline Butcher shop & 368 \\
\hline Purifying & 218 \\
\hline Clothing store & 88 \\
\hline Stockpile & 382 \\
\hline Tlapalería & 322 \\
\hline Cell Phone Accessories & 17 \\
\hline Internet & 216 \\
\hline Miscellany & 836 \\
\hline Naturist & 34 \\
\hline Cremeria & 285 \\
\hline
\end{tabular}

\begin{tabular}{|l|r|}
\hline Bonnet store & 61 \\
\hline Carpentry & 153 \\
\hline Plumbing & 28 \\
\hline Mechanical & 4 \\
\hline Shoe shop & 141 \\
\hline Smithy & 270 \\
\hline Tatto & 10 \\
\hline Vet & 73 \\
\hline Esthetic & 6 \\
\hline Furniture & 59 \\
\hline Billiards & 16 \\
\hline
\end{tabular}

\section{Table 1.6 Number of Businesses Chalco}

\section{Sample Selection}

The people who will participate in the sample will be selected, taking into account the experience they have had with the pandemic.

\section{Sample Calculation}

To calculate the sample, the finite general formula was used, which takes into account less than 500,000 inhabitants due to the number of businesses that are within the universe, which is a total of 9,973. As it's shown in the following: UNIVERS: 9,973

Formula:

$$
\mathrm{n}=\frac{\mathrm{O}^{2} \mathrm{pq} \mathrm{N}}{\mathrm{E}^{2}(\mathrm{~N}-1)+\mathrm{O}^{2} \mathrm{pq}}
$$

$\mathrm{n}=$ Sample size

$\mathrm{o}=$ Confidence level

$\mathrm{N}=$ Universe

$\mathrm{P}=$ Probability in favor

$\mathrm{q}=$ Probability against

$\mathrm{e}=$ estimation error

\section{Data}

$\mathrm{n}=$ ?

$$
\begin{aligned}
& \mathrm{O}=95 \%=95 / 2=47.5 / 100=0.475(1.96) \\
& \mathrm{N}=9973 \\
& \mathrm{P}=50 \% \\
& \mathrm{Q}=50 \% \\
& \mathrm{E}=0.05 \\
& \mathrm{n}=\frac{(1.96)^{2}(.5)(.5)(9973)}{3.8416(.5)(.5)(9973)} \\
& \mathrm{n}=\frac{(0.05)^{2}(9973-1)+(1.96)^{2}(.5)(.5)}{0.0025(9973-1)+3.8416}
\end{aligned}
$$

GUTIÉRREZ-ZEPEDA, Martha del Pilar. Solutions and strategies of Nezahualcoyotl's business before the pandemic. RINOE Journal- Macroeconomics and monetary economy. 2020 


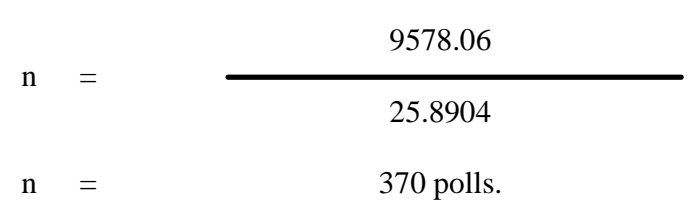

\section{Data collection}

Taking into account the results of the general formula, it is the total of surveys to be carried out to small businesses in Nezahualcóyotl and the Metropolitan Area that are registered in MyPes. This information collection instrument helped us to obtain the necessary results to solve the objective of this research, to maintain the objectivity of the answers these were closed, a pilot test was also carried out with $10 \%$ of our sample in order to to correctly structure each of the questions presented in the final questionnaire.

The information was collected online and in person at the businesses in Nezahualcóyotl and the Metropolitan Area by students Bravo Moreno Mónica Elizabeth \& Montoya Vázquez Jesús Rafael. from the Technological University of Nezahualcóyotl. The Technological University of Nezahualcóyotl of the Marketing Area Business Development career invites you to take the survey to know the impact that each business has in the face of the pandemic, this will help us to carry out strategies so that businesses can increase their sales.

Municipality where your business is located

$\begin{array}{ll}\text { a. } & \text { La paz } \\ \text { b. } & \text { Ixtapaluca } \\ \text { c. } & \text { Texcoco } \\ \text { d. } & \text { Chimalhuacán } \\ \text { e. } & \text { Chalco } \\ \text { f. } & \text { Nezahualcóyotl }\end{array}$

1. What is the line of your business?

a. Food industry

b. Electronic industry

c. Information technology

d. Other, which one?

2. Have you had any kind of financial support from the state government?

a. Yes, what is the support received from the state government?

b. No, Why?
3. Among what percentage do you identify that your business was affected by the pandemic?

$\begin{array}{ll}\text { a. } & 0 \%-40 \% \\ \text { b. } & 41 \%-60 \% \\ \text { c. } & 61 \%-80 \% \\ \text { d. } & 81 \%-100 \%\end{array}$

4. Do you use social media for your business?. If your answer was no, please go to question $\mathrm{n}^{\circ} 7$

$\begin{array}{ll}\text { a. } & \text { Yes } \\ \text { b. } & \text { No }\end{array}$

5. What is the social network you use?

a. Facebook

b. Instagram

c. YouTube

d. Other ¿Which one?

6. By what percentage have sales increased by uploading the products to social networks?
a. $\quad 5 \%-10 \%$
b. $\quad 15 \%-20 \%$
c. $\quad 25 \%-30 \%$
d. $35 \%$ onwards

7. What has been one of the solutions that has worked for your business during this pandemic?
a. Promotions
b. Home delivery of products
c. Discounts
d. Others, which one?

8. Have you had more competition during this pandemic?
a. Yes
What kind of competition?
b. No
9. How have you been able to pay for your merchandise?
a. Own means.
b. Bank loans
c. Familiar help
d. Others, which ones? 
10. What would you do with your business if the pandemic continues through 2021 ?

a. Move on Make the business transfer

b. Close up shop

c. Move on Make the business transfer

d. Others, which ones?

11. Do you know approximately how many businesses in your locality have closed during this pandemic?

a. $\quad 1$ to 5 businesses

b. $\quad 6$ to 10 businesses

c. $\quad 11$ to 15 businesses

d. More than 16 businesses

12. What are the means by which you have learned of the business closures during this pandemic?
a. Television and radio
b. Newspapers and magazines
c. Internet
d. Others, which ones?

\section{Observations}

\section{Chapter II Results}

\begin{tabular}{lr}
\hline \multicolumn{1}{c}{ Choices } & Percentage \\
La Paz & $11 \%$ \\
Ixtapaluca & $14 \%$ \\
Texcoco & $11 \%$ \\
Chimalhuacán & $18 \%$ \\
Chalco & $11 \%$ \\
Nezahualcóyotl & $35 \%$
\end{tabular}

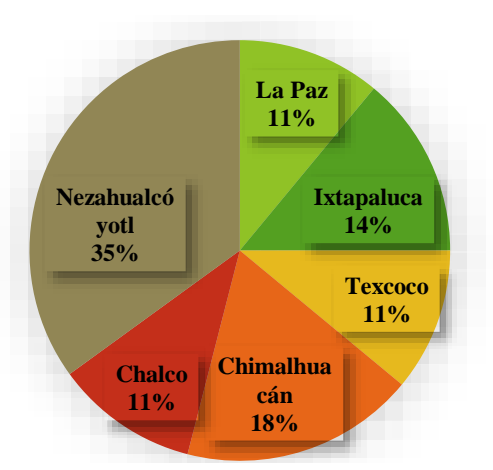

Graphic 2.1 Businesses interviewed Source: Own Authorship

The municipality most interviewed was in Ciudad Nezahualcóyotl with $35 \%$ of all interviews.

\begin{tabular}{lc}
\hline \multicolumn{1}{c}{ Choices } & $\%$ \\
\hline a) Food Industry & $34 \%$ \\
b) Electrical industry & $24 \%$ \\
c) Information technologies & $20 \%$ \\
d) Other & $22 \%$
\end{tabular}

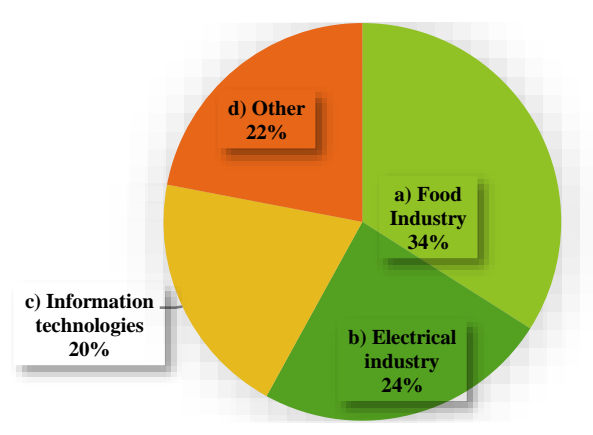

Graphic 2.2 Line of business Source: Own Authorship

According to this graphic representation, it tells us that most of the businesses are dedicated to the food industry.

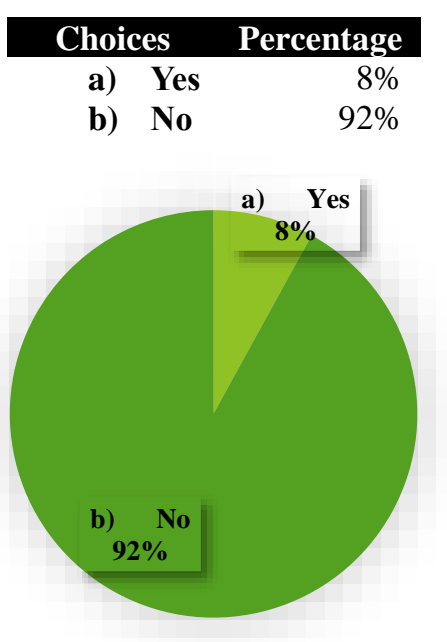

Graphic 2.3 Have you had any kind of financial support from the state government?

Source: Own Authorship

As shown, only $8 \%$ of businesses tell us that they do have financial support and while $92 \%$ of them report that they did not know about this government program. 


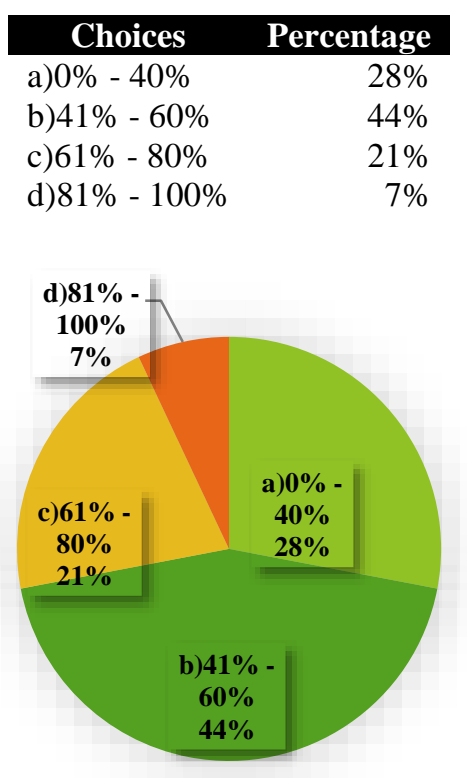

Graphic 2.4 Among what percentage do you identify that your business was affected by the pandemic?

Source: Own Authorship

As shown in the graph, it tells us that $44 \%$ of the businesses consider that between 41 and $60 \%$ have been affected by this pandemic.

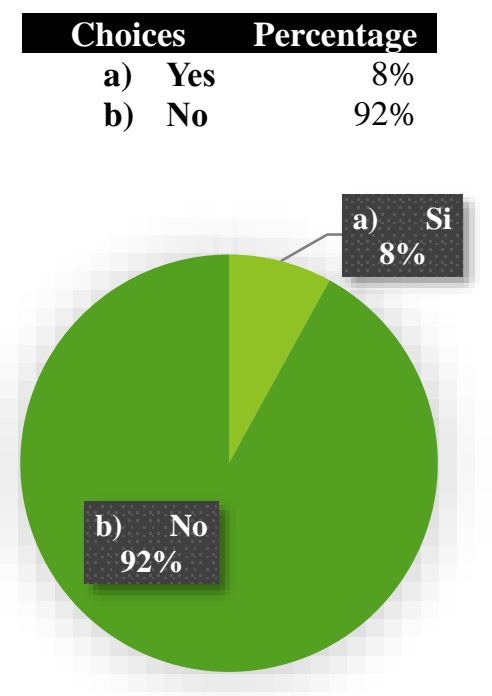

Graphic 2.5 Have you had any kind of financial support from the state government?

Source: Own Authorship

As shown in these results, they inform us that the majority did not know about the aid programs and some of them did not select them for these reasons, only $8 \%$ of the businesses do have financial support.

\section{Choices Percentage \\ a) Yes $53 \%$ \\ b) No $\quad 47 \%$}

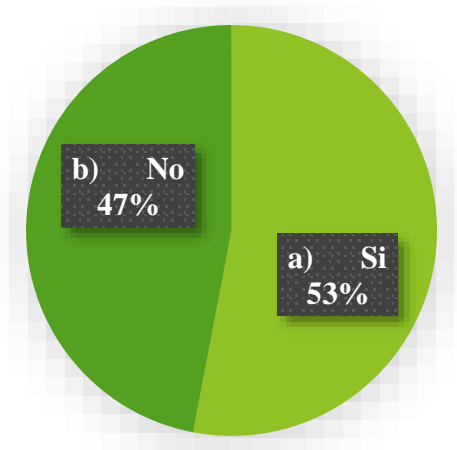

Graphic 2.6 Do you use social media for your business? Source: Own Authorship

As shown in these results, 53\% of businesses do use social networks, but they only report on the products, but not in the right places and they don't talk about their products but about other stories that are not related to their business.

\begin{tabular}{lr}
\hline Choices & Percentage \\
\hline a) $5 \%-10 \%$ & $43 \%$ \\
b) $15 \%-20 \%$ & $34 \%$ \\
c) $25 \%-30 \%$ & $19 \%$ \\
d) 35\% onwards & $4 \%$
\end{tabular}

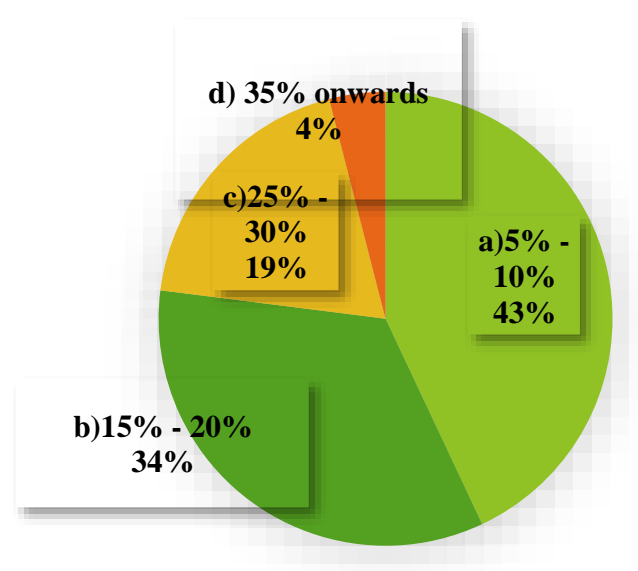

Graphic 2.7 By what percentage have sales increased by uploading the products to social networks?

Source: Own Authorship

As shown in this Figure, it tells us that $43 \%$ of businesses did help them spread their business on social media by approximately $10 \%$. 


\begin{tabular}{llr}
\hline Choices & Percentage \\
a) Promotions & $34 \%$ \\
b) Home delivery & $45 \%$ \\
c) Discounts & $20 \%$ \\
d) Other & $1 \%$
\end{tabular}

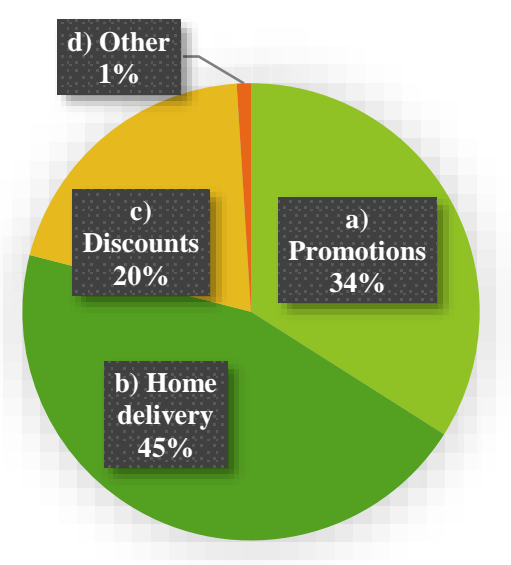

Graphic 2.8 What has been one of the solutions that has worked for your business during this pandemic? Source: Own Authorship

One of the most important strategies that have helped to improve sales are home deliveries by $45 \%$ and, secondly, sales promotions.

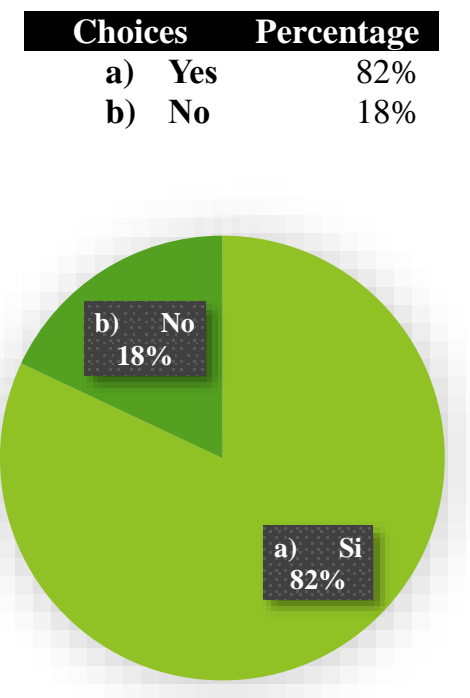

Graphic 2.9 Have you had more competition during this pandemic?

Source: Own Authorship

As the results show, $82 \%$ of the businesses in Nezahualcóyotl and the metropolitan area have had more competition than in other times.
Choices

\section{Percentage}

a) Own media $41 \%$

b) Bank loans 20\%

c) Family help 29\%

d) Other $10 \%$

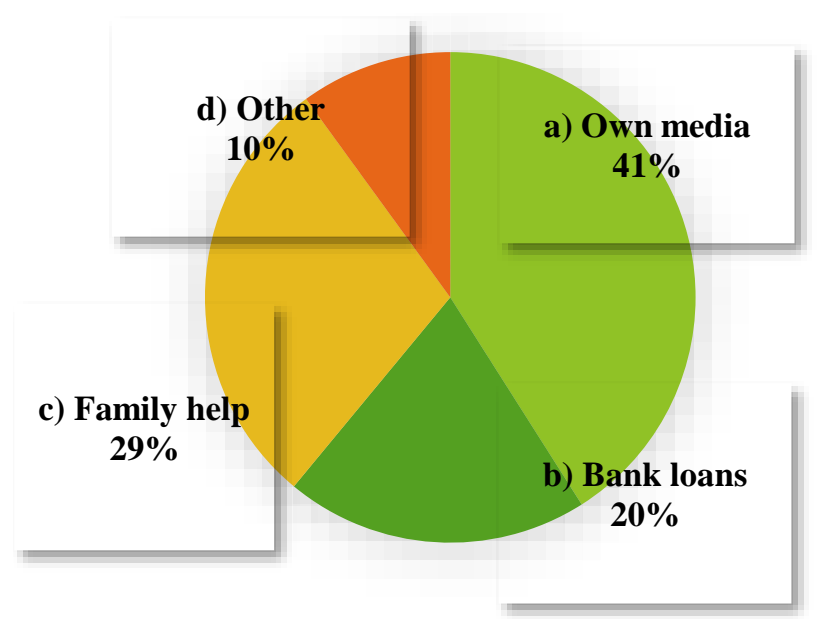

Graphic 2.10 How have you been able to pay for your merchandise?

Source: Own Authorship

As shown, $41 \%$ of merchants have paid their own expenses, while $29 \%$ say that their relatives help them.

\begin{tabular}{lr}
\hline Choices & Percentage \\
\hline a) keep going & $42 \%$ \\
b) Close the deal & $35 \%$ \\
c) Make transfer & $23 \%$ \\
d) Other & $0 \%$
\end{tabular}

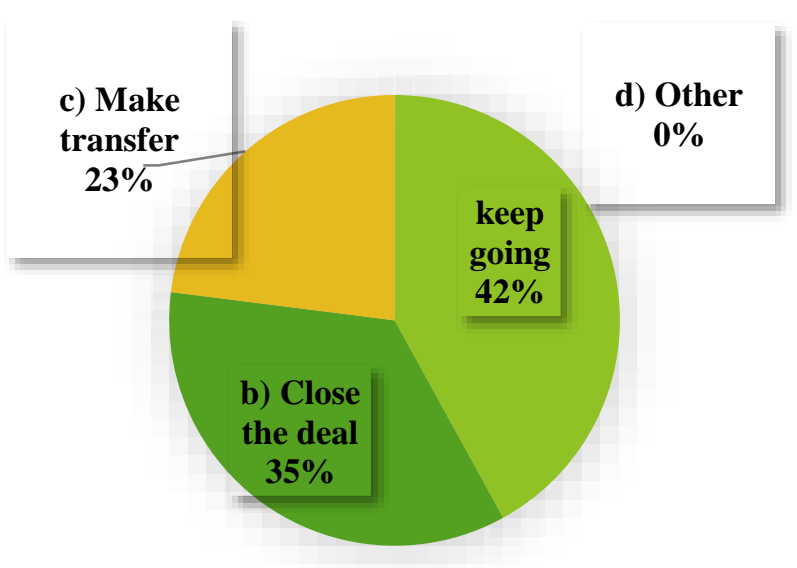

Graphic 2.11 What would you do with your business if the pandemic continues through 2021?

Source: Own Authorship

As shown in this representation, $42 \%$ say they will go ahead but a significant $35 \%$ say they will close the business. 


\begin{tabular}{lr}
\multicolumn{1}{c}{ Choices } & $\%$ \\
\hline a) 1 - 5 businesses & $35 \%$ \\
b) $\mathbf{6}-\mathbf{1 0}$ businesses & $33 \%$ \\
c) 11 - 15 businesses & $24 \%$ \\
d) More than 16 businesses & $8 \%$
\end{tabular}

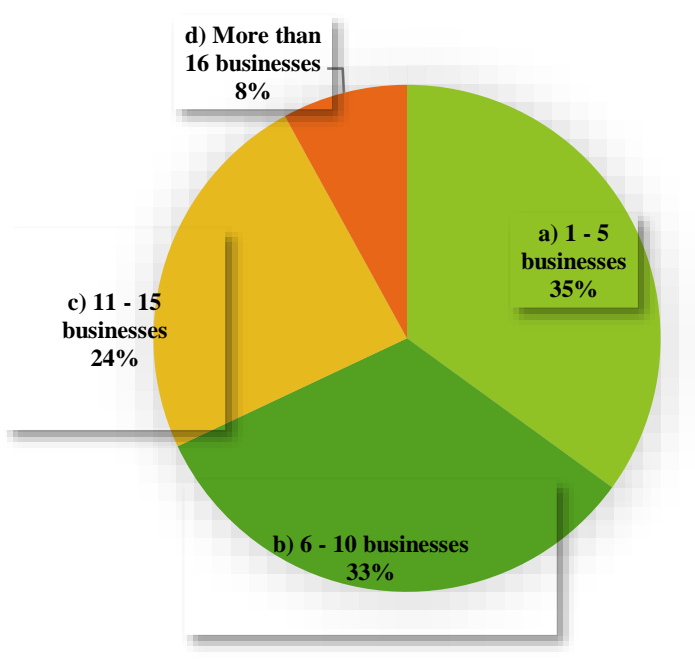

Graphic 2.12 Do you know about how many businesses in your area have closed during this pandemic? Source: Own Authorship

As shown in the results, $35 \%$ of the merchants tell us that between 1 to 5 businesses have closed, depending on the businesses that are in the locality due to the confinement.

\begin{tabular}{llr}
\hline \multicolumn{1}{c}{ Choices } & Percentage \\
a) & Television and Radio & $48 \%$ \\
b) Newspapers and Magazines & $21 \%$ \\
c) & Internet & $28 \%$ \\
d) & Other & $3 \%$
\end{tabular}

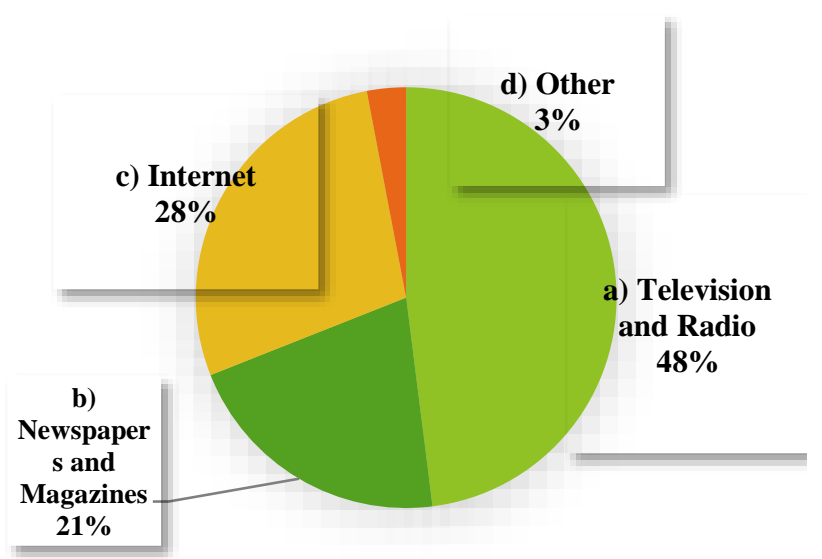

Graphic 2.13 What are the means by which you have learned of business closures during this pandemic?

\section{Source: Own Authorship}

As shown in these results, $48 \%$ of merchants tell us that they have learned more from radio and television than from social networks.

\section{Chapter III Conclusions and proposals}

According to the results obtained, we can conclude the following:

- The problems that have caused during this pandemic in the first place is the economic one derived from unemployment or decrease in wages, $42 \%$ of merchants report that they continue to move forward but that if the pandemic continues in the following year, unfortunately they will also close. Therefore, it is necessary to generate sales strategies that help them increase these through advertising in the most important social network in this area (Facebook) but generating marketing content (content that is related to the products that are sold but at the same time that they help the target audience and only in the locality) Another sales strategy can be home delivery, informing the delivery method through the same social network, informing the forms of sanitation security in the products delivered.

- The Secretary of Economic Development offers courses for the growth of their businesses such as The Secretary of Development Economico offers a course for the growth of its businesses such as the Official Online Store "Everything I find in CDMX" It offers preferential conditions to the MIPyMES of Mexico City for the commercialization of their products and services through an official online store in Mercado Libre to reach more consumers and strengthen the local economy. This can be seen at the following URLs. https://www.sedeco.cdmx.gob.mx/convocatoria s/cursos

- "Financial support for family microbusinesses, Credit to the word" are for businesses that have been working for more than 6 months and have to register in the welfare census, see credito_a_la_palabra (www.gob.mx)

In general, these strategies will help the businesses that are in the investigated area, but as long as the small businesses are willing to change the way they market their products and spread them. 


\section{Acknowledgments}

This article arose due to the concern that exists during this confinement because in Ciudad Nezahualcóyotl according to the press release of the Government of the Municipality it tells us that they offer more than 10,000 businesses such as restaurants, cheap kitchens, inns and other similar businesses (Bulletin Press, 2020) Due to the above, there was a growing concern to know what are the problems that businesses faced during this pandemic and what may happen if we do not guide them to continue working in a different way so that they can move forward.

Therefore, we are grateful for the participation of the students Mónica Elizabeth Bravo Moreno and Jesús Rafael Montoya Vázquez, students of the Technological University of Nezahualcóyotl for their support in the collection of information, as well as the Institution. Also for the participation of the businesses that provided their responses, which also commented that the pandemic has affected them a lot and that they appreciated that this study has been carried out because if they are very interested in generating strategies that they can implement without investing much so that can move on.

\section{References}

Dinero.com (2018) Habilitan registro en línea para PyMES recuperado en dinero.com.sv Habilitan registro en línea para MYPES

Gobierno Municipal Nezahualcóyotl (2020) Boletin de prensa Recuperado en $\mathrm{H}$. Ayuntamiento de Nezahualcóyotl

Hernández Sampieri R; Fernández C. \& Baptista P. (2014) Metodología de la investigación Metodología de la investigación - Sexta Edición (uca.ac.cr)

INEGI (2020) Encuesta sobre el Impacto Económico Generado por COVID-19 en las Empresas (ECOVID-IE) Recuperado en Encuesta sobre el Impacto Económico Generado por COVID-19 en las Empresas (ECOVID-IE) 2020 (inegi.org.mx)
Pymes.org.mx (2020) El directorio de MiPyMEs, PyMEs y Empresas + Grande de México Recuperado en PyMES.org.mx el directorio de MiPyMES, PyMEs y empresas más grande de México

Secretaría de Salud (14/08/2020) Lineamiento para la estimación de riesgos del semáforo por regiones COVID-19, Microsoft Word Metodo_semaforo_COVID_14Agosto2020_19 h00.docx (coronavirus.gob.mx)

Wang, W., Tang, J., \& Wei, F. (2020). Updated understanding of the outbreak of 2019 novel coronavirus (2019-nCoV) in Wuhan, China. Journal of Medical Virology.[ Internet] 2020 [citado 19 mar 2020] 20 (3). Disponible en: URL doi:10.1002/jmv.25689 